\title{
OTONOMI KHUSUS DAN PARTAI POLITIK LOKAL: ANALISIS KEBIJAKAN UNDANG-UNDANG PEMERINTAHAN ACEH NO 11 TAHUN 2006 TENTANG PARTAI POLITIK LOKAL
}

\author{
1Ahmad Murodi \\ 1 Universitas Islam Syekh-Yusuf, Tangerang \\ Email:ahmadmurodi@unis.ac.id
}

\begin{abstract}
Abstrak
Kebijakan tentang partai politik lokal di Aceh telah menimbulkan polemik terkait potensi disintegrasi yang mungkin terjadi sebagai akibat dibukanya akses politik bagi separatisme Aceh. Namun begitu Undang Undang No 11 Tahun 2006 tentang Pemerintahan Aceh merupakan bagian yang tak terpisahkan dari perjanjian damai antara Pemerintah Republik Indonesia dengan Gerakan Aceh Merdeka di Helsinski pada tahun 2005. Dengan dibukannya akses untuk terlibat langsung dalam ruang ruang politik diharapkan dapat menjadi kanal bagi kombatan GAM, untuk memperjuangkan aspirasinya melalui ruang politik lokal. Penelitian ini hendak menguji serta menganalis materi Undang Undang No 11 tahun 2006, terutama yang terkait tentang Otonomi khusus dan Politik Lokal dalam perspektif kebijakan publik.
\end{abstract}

Kata Kunci: 


\section{A. PENDAHULUAN}

Indonesia adalah sebuah negara multibangsa yang terdiri dari beragam suku, etnis, dan budaya yang membentuk sebuah negara kesatuan. Meskipun memiliki satu identitas nasional yang sama, namun tidak dapat dipungkiri bahwa masing-masing bangsa juga memiliki identitas suku, etnis, maupun budaya yang berbeda-beda yang tentunya juga memiliki aspirasi politik yang berbeda pula. Maka konsekuensi dari negara multibangsa adalah akan senantiasa dihadapkan pada persoalan integrasi politik dari beragam elemen yang membentuk bangsa. Selain itu mengelola potensi politik lokal adalah salah satu tantangan terbesar yang dimiliki oleh sebuah negara multibangsa demi menjaga integrasi nasional.

Indonesia di awal berdirinya pernah dihadapkan pada persoalan sulitnya mengelola integrasi nasional ditengah semaraknya pergolakan politik dan pemberontakan di daerah. Sejarah mencatat bahwa pasca kemerdekaan, Indonesia pernah menghadapi pemberontakan Darul Islam di Jawa Barat dan Sulawesi Selatan pada tahun 1947 dan 1950, PRRI di Sumatera Barat pada tahun 1958, pemberontakan RMS di Maluku, serta berdirinya Gerakan Aceh Merdeka di Aceh pada tahun 1976. Bahkan hingga saat ini Indonesia juga masih harus menghadapi gejolak politik di Papua yang terus menuntut berdirinya Papua Merdeka. Berbagai gejolak politik lokal tersebut menunjukkan bahwa sebagai sebuah negara multietnik, Indonesia dituntut untuk mampu mengelola aspirasi politik lokal demi menghindari potensi disintegrasi nasional.

Salah satu aspirasi politik lokal yang sejauh ini relatif mampu dikelola dengan baik oleh pemerintah Indonesia adalah politik lokal Aceh pasca perjanjian damai antara pemerintah Indonesia dengan Gerakan Aceh Merdeka di Helsinski tahun 2006. Sebelum tercapainya nota kesepahaman ini, Aceh merupakan sebuah wilayah yang penuh dengan konflik. Bahkan sekelompok intelektual yang tergabung dalam Gerakan Aceh Merdeka (GAM) pernah mendeklarasikan Aceh sebagai sebuah "negara" yang merdeka pada Desember 1976. ${ }^{1}$ Namun deklarasi ini tidak memiliki kekuatan politik tangguh sehingga gaungnya tidak begitu populer dikalangan masyarakat Aceh maupun dunia internasional. Bahkan deklarasi perlawanan GAM ini disambut oleh pemerintah pusat dengan menggelar Daerah Operasi Militer (DOM) di Aceh yang dimulai pada tahun 1989 hingga 1998.

\footnotetext{
${ }^{1}$ Nazarudin Sjamsuddin "Integrasi Politik di Indonesia" (Jakarta:Gramedia, 1989) hal 7071
}

77 I Pelita - Jurnal Penelitian dan Karya I lmiah 
OTONOMI KHUSUS DAN PARTAI POLITIK LOKAL:

ANALISIS KEBIJAKAN UNDANG-UNDANG PEMERINTAHAN ACEH NO 11 TAHUN 2006 TENTANG PARTAI POLITIK LOKAL

Ahmad Murodi

Gejolak di Aceh pada akhirnya dapat diselesaikan secara baik dengan ditandatanganinya Memorandum of Understanding (MOU) di antara kedua belah pihak yang bersengketa, yaitu Gerakan Aceh Merdeka (GAM) dan Pemerintah RI di Helsinski, Finlandia pada tahun 2005. Salah satu hasil dari kesepakatan tersebut, selain amnesti terhadap para anggota GAM yang menjadi tahanan politik, adalah Undang Undang Pemerintah Aceh No.11 Tahun 2006, yaitu otonomi yang luas kepada Aceh.

\section{Keabsahan Konstitusional Partai Lokal}

Salah satu produk dari Undang-Undang Pemerintah Aceh no 11 tahun 2006 adalah dibukanya peluang pendirian partai lokal di Aceh. Pembentukan partai lokal adalah sesuai dengan kesepakatan yang dicapai oleh Pemerintah RI dan GAM dalam butir 1.2.1 MoU Helsinski dimana pemerintah RI menyepakati dan memfasilitasi pembentukan partai politik yang berbasis di Aceh dan memenuhi persyaratan nasional. Selain itu dalam tempo satu tahun atau paling tidak 18 bulan sejak ditanda tanganinya nota kesepahaman, pemerintah RI akan menciptakan kondisi politik dan hukum untuk pendirian partai politik lokal di Aceh dengan konsultasi kepada DPR. ${ }^{2}$

Kesempatan untuk membentuk partai politik lokal di Aceh bukan tanpa polemik. Pro dan kontra muncul baik dalam proses pembuatan maupun implementasi kebijakan. Secara teknokratis kebijakan partai politik lokal di Aceh memang akan memicu beberapa persoalan. Kebijakan ibarat pisau bermata dua. Meskipun menjadi solusi paling riil dari upaya pemerataan pembangunan dan kesejahteraan di daerah, namun penerapannya mengandung resiko dalam memberikan kesempatan bagi munculnya potensi separatisme secara sistematis melalui partai politik lokal.

Tokoh-tokoh seperti Megawati, Abdurrahman Wahid, Hazim Muzadi, dan lain-lain mengkhawatirkan bahwa partai politik lokal di Aceh akan dijadikan kendaraan bagi gerakan separatisme. Bahkan menurut hasil survei Lembaga Survei Indonesia, 75.8 persen dari masyarakat Indonesia juga menolak kemunculan partai lokal. Sebanyak 76.2 persen secara spesifik menolak kehadiran partai lokal di Aceh. ${ }^{3}$ Hasil survei ini menunjukkan kekhawatiran masyarakat bahwa partai politik lokal justru

\footnotetext{
${ }^{2}$ Elidar Sari "Keberadaan Partai Politik Lokal di Indonesia:Kajian Terhadap Partai Politik Lokal di Aceh" (Jurnal Suloh: 2 Agustus 2008) Vol VI hal 4

${ }^{3}$ Survei LSI: Rakyat Tak Dukung Parpol Lokal, Sinar Harapan, 16 August 2005; Partai Lokal, Ujian Eksistensi GAM di NAD', Suara Karya, 22 August 200,
} 
akan memberikan wadah bagi GAM dalam arena politik untuk melepaskan Aceh dari Indonesia

Selain kekhawatiran akan potensi separatisme, tuntutan akan partai lokal dianggap bertentangan dengan undang-undang tahun 2008 tentang partai politik yang belum memberi celah bagi dibentuknya partai lokal. Undang-undang tentang partai politik meniscayakan representasi partai secara nasional, yang mustahil dipenuhi oleh partai politik lokal. Selain itu nota kesepahaman Helsinski tentang partai lokal juga masih sangat kabur terkait dengan definisi, mekanisme pemilu yang melibatkan partai lokal, serta bagaimana hubungan partai lokal dengan partai politik nasional. Namun disisi lain, partai lokal dianggap sebagai satu-satunya instrumen bagi masyarakat lokal untuk menyampaikan aspirasi politik lokalnya ketika partai nasional cenderung sentralistis. ${ }^{4}$ Selain itu, dalam rangka resolusi konflik, sangat penting untuk menampung aspirasi masyarakat Aceh, terutama mantan kombatan GAM dalam wadah partai lokal, ditengah ketidakpercayaan masyarakat terhadap partai nasional.

Kesempatan untuk berpartisipasi dalam konstelasi politik lokal ini tampaknya dimanfaatkan dengan sangat baik oleh eksponen GAM dengan terlibat langsung dalam Pilkada Aceh pada tahun 2006 dan Pilgub 2007 melalui jalur independen. Hal ini mengingat penerapan nota kesepahaman pemerintah RI dan GAM di Helsinski tentang pembentukan partai politik lokal belum bisa diwujudkan dalam Pilkada ini. Hasilnya, dari 21 kabupaten/kota yang melaksanakan pilkada, delapan diantaranya dimenangkan oleh kader-kader GAM melalui jalur independen. Begitu juga dengan pilkada putaran 2008 di Bireun dan Pidie Jaya yang juga dimenangkan oleh kelompok GAM. ${ }^{5}$ Bahkan pada pemilihan gubernur (pilgub) Aceh 2007, GAM berhasil menempatkan dua kadernya yaitu Irwandi Yusuf dan Muhammad Nazar sebagai orang nomer satu di Provinsi Aceh.

Kebijakan tentang partai politik lokal yang termuat dalam UUPA no 11 tahun 2006 tampaknya memiliki penjelasan yang lebih meyakinkan apabila ditinjau dalam perspektif proses pembuatan kebijakan secara politis. Partai politik lokal adalah sebuah kompromi antara Pemerintah RI dan GAM dalam upaya menyelesaikan gerakan separatisme Aceh. Undang-undang PA no 11 tahun 2006 secara keseluruhan adalah sebuah tawaran politik dari GAM dengan imbalan, menghentikan segala upaya

${ }^{4}$ Elidar Sari “Keberadaan Partai Politik Lokal di Indonesia:Kajian Terhadap Partai Politik Lokal di Aceh" (Jurnal Suloh: 2 Agustus 2008) Vol VI hal

${ }^{5}$ Moch Nurhasim "Tranformasi Politik Gerakan Aceh Merdeka (GAM)" hal 87

79I Pelita - Jurnal Penelitian dan Karya Ilmiah 
separatisme untuk lepas dari NKRI. Maka, meskipun secara teknis bermasalah, pemerintah dengan berbagai pertimbangan, dan setelah melalui tawar menawar yang cukup alot akhirnya membuka kemungkinan bagi dibentuknya partai politik lokal di Aceh.

\section{B. LANDASAN TEORI}

William Dunn mengemukakan beberapa tahap dalam proses kebijakan publik 6 :

\section{a. Penyusunan agenda.}

Para pejabat yang dipilih dan diangkat menempatkan masalah pada agenda publik. Sebelumnya masalah-masalah tersebut berkompetisi terlebih dahulu untuk dapat masuk ke dalam agenda kebijakan. Pada akhirnya, beberapa masalah masuk ke agend kebijakan para perumus kebuijakan. Pada tahap ini suatu masalah mungkin tidak di sentuh sama sekali dan beberapa yang lain pembahasan untuk maslaah tersebut di tunda untuk waktu yang lama.

b. Formulasi kebijakan

Masalah yang telah masuk ke agenda kebijakan dibahas oleh para pembuat kebijakan. Masalah-masalah tersebut didefinisikan untuk kemudian di cari pemecahan yang terbaik. Masing-masing alternatif bersaing untuk dapat dipilih sebagai kebijakan yang di ambil untuk memecahkan masalah.

\section{c. Adopsi kebijakan}

Salah satu alternatif kebijakan tersebut di adopsi dengan dukungan dari mayoritas hingga menghasilkan consensus antara direkur lembaga / keputusan peradilan.

\section{d. Implementasi kebijakan}

Kebijakan yang telah di ambil sebgaai alternatif pemecahan masalah harus diimplementasikan, yakni dilaksanakan oleh badan-badan administasi maupun agen-agen pemerintah di tingkat bawah. Kebijakan yang telah diambil dilaksanakan oleh unit-unit adminisrasi yang memobilisasi sumberdaya finansial dan manusia. Pada tahap implementasi ini berbagai kepentingan akan bersaing. Beberapa implementasi kebijakan

\footnotetext{
${ }^{6}$ Wiiliam N. Dunn, "pengantar analisis Kebijakan Publik”, edisi II, Yogyakarta: Gadjah Mada University Press, 2000. Halm. 26
} 
mendapat dukungan para pelaksana, namun beberaa yang lain mungkin akan di tentang oleh pelaksana.

e. Evaluasi kebijakan

Kebijakan yang telah di laksanakan akan dinilai/ di evaluasi untuk melihat sejauh mana kebijakan yang telah di buat mampu memecahkan masalah. Kebijakan publik pada dasarnya di buat untuk meraih dampak yang diinginkan. Dalam hal ini, memperbaiki masalah yang di hadapi masyarakat. Oleh karena itu, ditentukan ukuran-ukuran/ kriteria yang menjadi dasar untuk menilai apakah kebijakan publik telah meraih dampak yang diingikan.

Kebijakan adalah suatu proses, untuk itu, evaluasi ini di gunakan untuk keperluan jangka panjang dan untuk kepentingan keberlanjutan suatu program. Dengan evaluasi, kebijakan-kebijakan ke depan akan lebih baik dan tidak mengurangi kesalahan yang sama. Dari hasil evaluasi, diharapkan dapat di tetapkan kebijakan yang lebih baik. ${ }^{7}$

Berikut adalah bagan yang menjelaskan kebijakan sebagai suatu proses:

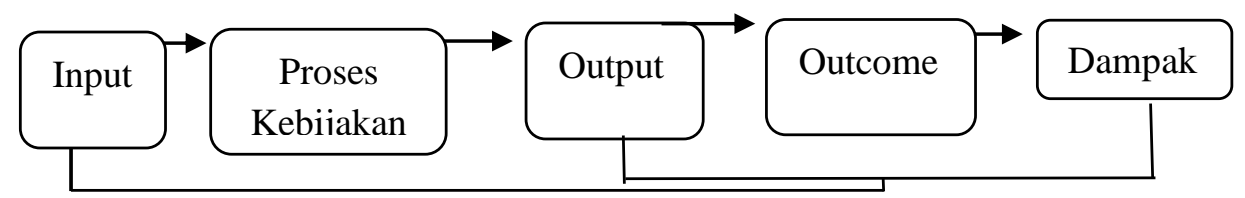

Gambar 1. Kebijakan Suatu Proses

Potensi munculnya aspirasi politik lokal adalah sebuah konsekuensi dari terbentuknya negara multibangsa seperti Indonesia. Menurut Will Kymlicka, yang disebut sebagai negara multibangsa adalah bergabungnya berbagai kebudayaan kedalam satu teritorial negara-bangsa. Kebudayaankebudayaan yang bergabung tersebut ingin mempertahankan diri sebagai masyarakat tersendiri dan menuntut berbagai bentuk otonomi demi keberlangsungan masyarakatnya sendiri. Sedangkan kebudayaan yang lebih kecil membentuk minoritas bangsa yang juga seringkali menuntut otonomi demi keberlangsungan mereka. Dalam hal ini kelompok Indian yang berusaha mencari otonomi ditengah bangsa-bangsa yang membentuk

\footnotetext{
${ }^{7}$ Op cit, A. G Subarsono, Halm. 124

${ }^{8}$ Ibid, hal. 121
}

81 Pelita - Jurnal Penelitian dan Karya Ilmiah 
Amerika Serikat dapat disebut sebagai minoritas bangsa. Begitu juga dengan orang-orang Quebec dan Aborigin di Kanada. ${ }^{9}$

Dalam sebuah negara dengan keragaman bangsa, budaya dan etnis, persoalan integrasi seringkali menjadi isu penting yang harus dikelola dengan baik demi menjaga keutuhan negara. James J.Coleman dan Carl G Rosberg melihat bahwa integrasi nasional memiliki dua dimensi, yaitu vertikal (elit-massa) dan horisontal atau teritorial. Integrasi politik lebih cenderung bersifat vertikal yang bertujuan untuk menjembatani celah perbedaan antara elit dan massa. Sedangkan yang dimaksud dengan integrasi teritorial adalah integrasi secara horisontal dengan tujuan untuk mengurangi ketegangan kultur kedaerahan dalam rangka proses penciptaan suatu masyarakat politik yang homogen. ${ }^{10}$

Sedangkan Claude Ake menyebutkan bahwa integrasi politik melibatkan dua masalah penting yaitu bagaimana membuat rakyat tunduk dan patuh kepada tuntutan negara serta bagaimana meningkatkan konsensus normatif yang mengatur tingkah laku politik anggota masyarakat. ${ }^{11}$ Untuk mengatasi kedua masalah tersebut Myron Weiner menawarkan dua pendekatan yaitu asimilasi dan persatuan dalam keanekaragaman. Asimilasi merupakan sebuah pendekatan dimana kebudayaan suku yang dominan dijadikan sebagai kebudayaan nasional dengan menundukkan kebudayaan dan identitas minoritas kedalam kebudayaan dominan. Sedangkan strategi persatuan dalam keanekaragaman mensyaratkan pembentukan kesetiaan nasional dilakukan dengan tidak menghilangkan kebudayaan dan kelompok minoritas. ${ }^{12}$

Selain pendekatan asimilasi dan persatuan, desentralisasi merupakan salah satu pendekatan yang cukup efektif dalam mengelola aspirasi politik lokal demi menjaga integrasi nasional. Desentralisasi dianggap mampu untuk mengatasi masalah ekonomi dan kesenjangan sosial akibat dari pembangunan yang tidak merata. Namun desentralisasi juga bukanlah sebuah kebijakan yang tanpa polemik. Di beberapa negara, elit politik yang berkuasa seringkali alergi dengan desentralisasi. Argumentasi yang biasanya dibangun untuk menolak penyebaran

\footnotetext{
${ }^{9}$ Will Kymlicka "Kewarganegaraan Multikultural” Jakarta: Kanisius, 2007, hal 145

10 James J Coleman and Carl G Rosberg "Political Parties and National Integration in Tropical Africa" (Berkeley, Los Angeles: University of California Press, 1964) hal 8-9 dikutip dari Op.cit., "Integrasi Politik di Indonesia" hal 2-3.

${ }^{11}$ Op.cit., "Integrasi Politik di Indonesia" hal 6
} 
kekuasaan adalah bahwa desentralisasi akan memberikan ruang bagi munculnya kekuatan lokal yang akan membahayakan persatuan nasional. Pada akhirnya desentralisasi justru akan berujung kepada disintegrasi dan destabilisasi sistem politik. Kekhawatiran lain dari kebijakan desentralisasi adalah kekuasaan di daerah justru akan didominasi oleh kasta-kasta lokal dan dimanfaatkan demi kepentingan mereka sendiri. ${ }^{13}$

\section{Partai Politik Lokal di Aceh dan Masalah Integrasi}

Partai politik di Aceh adalah bagian dari kompromi politik antara pihak Pemerintah Indonesia dengan Gerakan Aceh Merdeka, dalam rangka menghasilkan perdamaian di propinsi tersebut, dengan konsekuensi bahwa Gerakan Aceh Merdeka akan meninggalkan cara-cara kekerasan dan meninggalkan cita-cita mereka untuk melepaskan diri dari NKRI. Partai politik lokal Aceh adalah juga kompromi dari tidak tersalurkannya aspirasi politik masyarakat Aceh sebelum nota kesepahaman tercapai. Maka pada tahun 2009 tercatat ada 6 partai lokal yang lolos verifikasi serta mengikuti pemilu dan bersaing dengan partai-partai nasional yang lain.

Keenam partai lokal tersebut adalah Partai Aceh (PA), Partai Daulat Aceh (PDA), Partai Aceh Aman Sejahtera (PAAS), Partai Suara Independen Rakyat Aceh (SIRA), Partai Rakyat Aceh (PRA), dan Partai Bersatu Aceh (PBA). Dari keenam partai lokal tersebut, yang paling menarik perhatian adalah Partai Aceh, yang merupakan representasi para mantan kombatan GAM. Pimpinan GAM mendeklarasikan berdirinya partai ini pada tanggal 7 Juli 2007 dengan nama Partai GAM, dan memiliki bendera GAM. Meskipun pada akhirnya partai ini berganti nama menjadi Partai Aceh, namun kentalnya nuansa GAM dalam partai ini mau tidak mau menimbulkan kecurigaan besar bahwa Partai Aceh menyimpan potensi laten dari semangat separatisme GAM.

Pemilu legislatif 2009 menunjukkan hasil diluar dugaan banyak pengamat, sekaligus semakin menambah kekhawatiran masyarakat bahwa ide tentang partai lokal akan menjadi masalah bagi integrasi politik Aceh kedalam NKRI. Partai Aceh mendominasi pemilu lokal sampai pada level yang belum pernah dicapai oleh partai politik manapun semenjak Indonesia kembali ke alam demokrasi di tahun 1999. Meskipun tidak memenuhi targetnya sendiri yang sangat tinggi, Partai Aceh berhasil memperoleh 46.91 persen suara, yang diwujudkan dalam 33 kursi dari total

\footnotetext{
${ }^{13}$ Rajni Kothari "Issues in Decentralized Governance" dalam "Decentralization and Local Politics" (New Delhi: Sage Publication, 1999) hal 47-53
} 
OTONOMI KHUSUS DAN PARTAI POLITIK LOKAL:

69 kursi DPRD provinsi dan lebih dari sepertiga kursi yang diperebutkan di 23 DPRD Kabupaten dan Kota. ${ }^{14}$

Kemenangan Partai Aceh mau tidak mau telah memberikan sebuah gambaran penting tentang betapa kuatnya pengaruh GAM serta bagaimana sesungguhnya aspirasi masyarakat Aceh terkait dengan integrasi politik Aceh. Kemenangan partai inkarnasi GAM ini paling tidak disebabkan oleh beberapa faktor. Pertama, kemampuan partai ini untuk memobilisasi jaringan mantan kombatan membuat partai ini memiliki kemampuan organisasi yang luar biasa. Kedua, Partai Aceh melakukan kampanye yang sederhana tetapi efektif untuk mempresentasikan dirinya sebagai partai lokal yang paling otentik. Tiga, Partai Aceh berhasil meyakinkan masyarakat yang trauma dengan konflik bahwa satu suara untuk Partai Aceh adalah satu suara untuk perdamaian Aceh. Terdapat bukti yang menunjukkan bahwa sejumlah pemilih merasa takut konflik akan kembali terjadi jika Partai Aceh tidak berhasil memenangkan kesempatan untuk berkuasa. Di samping itu, banyak pemilih di Aceh yang berpendapat bahwa Partai Lokal Aceh layak untuk mendapatkan kesempatan mengelola kekuasaan di Aceh, setelah puluhan tahun pemerintah pusat menunjukkan kinerja yang buruk terhadap kesejahteraan rakyat Aceh. ${ }^{15}$

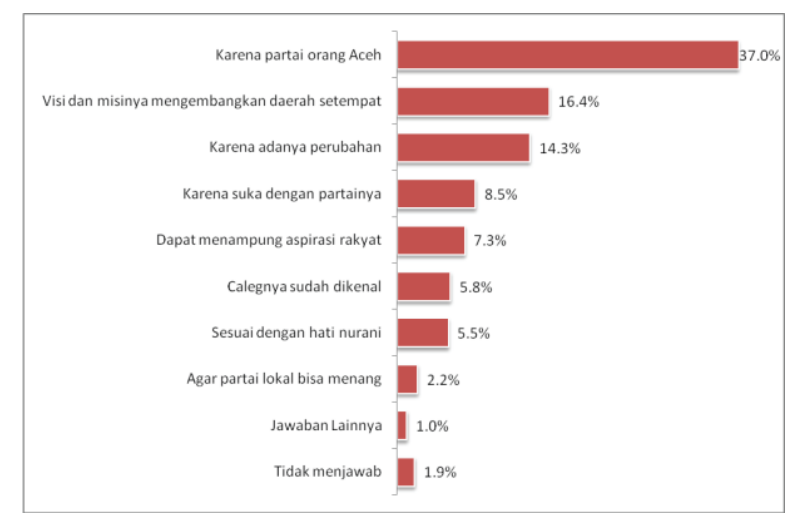

Gambar 2.

Diagram Alasan memilih partai lokal dalam pemilihan umum legislatif 2009

(Sumber: Australia Indonesia Governance Research Partnership)

\footnotetext{
${ }^{14}$ Mawardi Ismail et.al "Partai Politik Lokal di Indonesia: Sebuah Uji Coba di Aceh" (Australia-Indonesia Governance Research Partnership: The Australian National University Press, 2009) hal 4

${ }^{15}$ Ibid., hal 5
}

84 I Pelita - Jurnal Penelitian dan Karya Ilmiah 
Kemenangan Partai Aceh sebagai representasi dari kekuatan politik lokal juga memberikan sebuah persoalan tentang bagaimana relasi antara pemerintah pusat dengan daerah terkait dengan perangkat hukum yang mengatur tentang kewenangan Pemerintah Daerah Aceh. Hal ini mengingat bahwa landasan legal-formal otonomi khusus bagi Pemerintah Aceh termaktub dalam Undang-Undang Pemerintah Aceh (UUPA) yang merupakan produk dari DPR RI. Sedangkan Partai Lokal Aceh tidak memiliki wakil di DPR RI, karena partai lokal hanya diizinkan mengikuti pemilu lokal. Kondisi ini membuat partai lokal, terutama Partai Aceh merasa bahwa kekuasaan Pemerintah Pusat melalui DPR RI masih terlalu besar dalam menentukan masa depan rakyat Aceh. Sesuatu yang dianggap belum sesuai dengan nota kesepahaman Helsinski dimana rakyat Aceh melalui partai lokal diberi otonomi luas untuk mengelola Pemerintah Daerah Aceh.

Maka kemudian muncul inisiatif untuk memberikan kesempatan bagi partai lokal untuk memperebutkan kursi DPR RI. Sebuah inisiatif yang mendapatkan dukungan luas masyarakat Aceh namun cukup sulit untuk diimplementasikan. Kompromi paling realistis dari menciptakan jaringan aliansi informal antara partai lokal dengan partai nasional yang akan membawa kepentingan partai lokal di tingkat nasional. Dalam hal ini Partai Demokrat mendapatkan momentum untuk mengadakan koalisi dengan Partai Aceh, dengan membawa aspirasi Partai Aceh dilevel DPR RI. Opsi lain dari upaya menjalin relasi antara Partai Lokal dengan Pusat adalah memperbolehkan adanya rangkap keanggotaan partai, dimana dalam hal ini anggota partai lokal disaat yang bersamaan dapat menjadi anggota partai nasional. ${ }^{16}$

Kemenangan partai lokal ini menunjukkan bahwa masyarakat Aceh lebih percaya untuk menyalurkan aspirasi politiknya kepada representasi politik lokal daripada nasional. Kemenangan Partai Aceh dalam pemilu lokal juga semakin menegaskan bahwa potensi politik lokal sangat penting untuk dikelola dengan baik. Sejauh ini, keberadaan partai politik lokal di Aceh dianggap mampu mengalihkan potensi separatisme di Aceh kedalam sebuah iklim politik yang demokratis. Partai politik lokal di Aceh juga menjadi sarana integrasi masyarakat Aceh dalam wadah NKRI.

Wacana tentang partai lokal ini sebenarnya tidak hanya muncul di Aceh. Usulan untuk membentuk partai lokal juga pernah muncul di beberapa daerah konflik seperti Papua. Dalam pasal 28 UU no 21/2001 tentang otonomi khusus Papua menyebutkan bahwa penduduk Provinsi

${ }^{16}$ Pasal 83, Undang-Undang Pemerintahan Aceh (Undang-Undang No.11/2006).

85 I Pelita - Jurnal Penelitian dan Karya Ilmiah 
Papua dapat membentuk partai politik. Namun pasal ini kemudian terhalang oleh Undang-Undang tentang partai politik yang tidak membuka peluang bagi dibentuknya partai lokal. ${ }^{17}$ Maka ketika partai nasional absen dalam memperjuangkan aspirasi politik masyarakat Papua, separatisme seolah-olah menjadi sarana bagi masyarakat untuk menyampaikan pesanpesan politiknya. Dalam hal ini kualitas demokrasi di level lokal sangat berpengaruh terhadap persoalan integrasi bangsa.

Selain itu, dalam konteks politik lokal, separatisme bukan lah fenomena yang muncul karena eksistensi partai politik lokal, namun lebih kepada ketidakadilan, kesewenang-wenangan, tersumbatnya aspirasi, serta maraknya penyalahgunaan kekuasaan disuatu wilayah. Selain itu persoalan kesejahteraan seringkali menjadi faktor pendorong terbesar yang dapat memicu munculnya potensi separatisme. ${ }^{18}$ Kehadiran partai politik lokal disatu sisi dapat dijadikan instrumen bagi masyarakat di daerah untuk menyalurkan aspirasi mereka. Dalam hal ini aspirasi yang mengarah kepada disintegrasi bangsa harus direspon dengan kebijakan yang berpihak kepada masyarakat lokal sehingga tercipta pemerataan pembangunan dan kesejahteraan bagi semua masyarakat.

\section{PENUTUP}

Dalam konteks masyarakat Aceh faktor utama penyebab munculnya masalah integrasi tidak banyak disebabkan oleh faktor identitas dan etnisitas, melainkan faktor ketidakpuasan terhadap pemerintah pusat yang sejak lama menempatkan Aceh secara diskriminatif dalam hal pembangunan dan kesejahteraan. Argumentasi yang menyatakan bahwa partai politik lokal akan memperuncing perpecahan daerah atau etnis sejauh inii tidak terbukti di Aceh.

Keberadaan partai politik lokal di Aceh sejauh ini bisa dijadikan contoh bagaimana resiko disintegrasi bisa dicegah. Undang-Undang mensyaratkan komitmen partai lokal dan anggota anggotanya untuk bekerja dalam kerangka konstitusional Negara Kesatuan Republik Indonesia. Sampai saat ini, pengalaman Aceh menunjukkan bahwa, jika ditangani dengan baik, partai politik lokal akan membantu membangun legitimasi dan menyediakan akses politik kepada komunitas yang mungkin, tanpa hal ini, tidak akan terwakili dalam sistem politik nasional.

\footnotetext{
${ }^{18}$ Op.cit., "Keberadaan Partai Politik Lokal di Indonesia: Kajian Terhadap Pembentukan Partai Politik Lokal di Aceh" hal 152.
}

86I Pelita - Jurnal Penelitian dan Karya Ilmiah 


\section{Referensi}

Coleman, J. J., and Rosberg, C. G. (1964). Political Parties and National Integration in Tropical Africa. Berkeley, Los Angeles: University of California Press.

Dunn, W. N. (2000). Pengantar analisis Kebijakan Publik, edisi II, Yogyakarta: Gadjah Mada University Press.

Ismail, M.et.al. (2009). Partai Politik Lokal di Indonesia: Sebuah Uji Coba di Aceh. Australia-Indonesia Governance Research Partnership: The Australian National University Press.

Kothari, K. (1999). Issues in Decentralized Governance dalam Decentralization and Local Politics. New Delhi: Sage Publication.

Kymlicka, W. (2007). Kewarganegaraan Multikultural. Jakarta: Kanisius.

Sari, E. (2008). Keberadaan Partai Politik Lokal di Indonesia: Kajian terhadap Partai Politik Lokal di Aceh. Jurnal Suloh. Vol V1, 2 Agustus 2008.

Sjamsuddin, N. (1989). Integrasi Politik di Indonesia. Jakarta: Gramedia. 